\title{
Aksjologiczny zamęt wyzwaniem dla współczesnego człowieka*
}

\section{KEYWORDS}

axiological confusion, truth, human dignity, manipulation, criticism

\begin{abstract}
Kmiecikowski Waldemar, Aksjologiczny zamęt wyzwaniem dla współczesnego człowieka [Axiological confusion as a challenge for modern man]. Kultura Społeczeństwo - Edukacja nr 1(13) 2018, Poznań 2018, pp. 71-81, Adam Mickiewicz University Press. ISSN 23000422. DOI 10.14746/kse.2018.13.5.
\end{abstract}

The article presents the category of axiological confusion understood as an important trait of reality that can be experimentally experienced by a modern man. The man is losing the ability not only to appropriately grasp one's own human nature and the essence of the moral good, but also the ability of cognitive opening oneself to the intelligibility of being. A modern homo sapiens neutralises the need to seek the truth. After all, the truth ceases to be both a transcendental property of being and a superior value that is the very foundation of a rational discourse on the philosophical imponderabilia.

Aksjologia jest ściśle związana z moralnością. Współczesny człowiek winien być nie tylko wykształcony, lecz także - jak pisał Leszczyński - „moralny z wyboru”.

* Wykład wygłoszony 15 października 2016 r. na inauguracji roku akademickiego w Wyższej Szkole Humanistycznej im. Króla Stanisława Leszczyńskiego w Lesznie. Rozpoczynał się od słów: Szanowny Panie Rektorze, Szanowny Panie Kanclerzu, Szanowne Grono Profesorskie, Szanowni Studenci i Zaproszeni Goście. Szanowni Państwo. Dziękuję Panu Rektorowi za zaszczyt wygłoszenia wykładu na inauguracji kolejnego roku akademickiego. Tym bardziej czuję się wyróżniony, że znajdujemy się w Wyższej Szkole Humanistycznej im. Króla Stanisława Leszczyńskiego, co zdaje się oznaczać, że przestrzeń, która nas otacza, (mówiąc nieco metaforycznie) wypełniona jest - a przynajmniej powinna być - duchem humanistyki, czyli tej wielokierunkowej refleksji nad człowiekiem, która nie może się obyć bez rudymentów filozoficznych. Ale to oznacza również, że towarzyszy nam także (przynajmniej symbolicznie) duch Stanisława Leszczyńskiego - króla, mecenasa sztuki, lecz również tego - kto polemizując z Janem Jakubem Rousseau - twierdził, że wykształcony człowiek ,jest moralny z wyboru, [że] jego cnota jest ugruntowana". Oba wymienione motywy w pewnym stopniu możemy odnaleźć w temacie naszego wykładu - „Aksjologiczny zamęt wyzwaniem dla współczesnego człowieka”. 
Jak jednak być „moralnym z wyboru”, skoro żyjemy w aksjologicznym zamęcie, czyli w stanie fundamentalnego nieporozumienia dotyczącego istoty dobra i zła, tego, co prawdziwe i fałszywe, piękne i szpetne, ale także tego, co rozsądne i nierozsądne; skoro żyjemy w przestrzeni nieporozumienia dotyczącego natury człowieka, jego przeznaczenia czy nawet natury samego myślenia? Warto w tym miejscu przytoczyć refleksje Elżbiety Okońskiej i Krzysztofa Stachewicza, którzy twierdzą:

według diagnoz wielu współczesnych myślicieli następuje „schłodzenie” wartości, a wręcz proces ich równoważności i wymienności. Wartości przeświecają przez siebie wzajemnie każda wartość zezuje zza innej, żyjemy (...) w czasach powszechnego „zeza wartości”; zło zezuje zza dobra, piękno zza brzydoty, kobiecość zza męskości etc. (Okońska, Stachewicz, 2009: 17)

Aby dostrzec ów aksjologiczny zamęt, trzeba pozwolić sobie na pewien wgląd filozoficzny. Pojawia się tutaj oczywiście niebezpieczeństwo, że prelegent zamknie się w przestrzeni abstrakcji i oderwie się za chwilę zupełnie od realiów życiowych. Wszak większość z nas zazwyczaj hołduje maksymie „nie filozofuj, przestań filo-

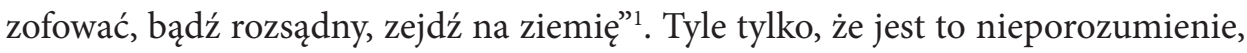
albowiem rzetelne filozofowanie to twarde, prawdziwe stapanie po ziemi. Zatem: więcej filozofii, więcej myślenia! To hasłowe wezwanie jest tym bardziej zasadne, że dzisiaj cierpimy na deficyt rozumowania. Przypuszczam, że w tym momencie część słuchaczy zaprotestuje i zada - w swym założeniu - retoryczne pytanie: czyż my nie myślimy, czyż nie rozumujemy? Przecież mamy dostęp do informacji w takiej skali, jakiej nie zna historia człowieka. Przecież, wchodząc w wirtualną przestrzeń, wnikamy w wielość informacji, obrazów, stwierdzeń, opinii, faktów, utworów muzycznych, dzieł filmowych itp.

Taka możliwość zdaje się być istotnym stygmatem współczesnego człowieka, który - kliknąwszy myszką - może się dowiedzieć, że $\mathrm{E}=\mathrm{mc}^{2}$, że wszechświat nieustannie się rozszerza, że oddychanie komórki zachodzi w mitochondriach, a także, że można już klonować zwierzęta i mrozić zarodki człowieka wyprodukowane $\mathrm{w}$ warunkach laboratoryjnych. Wobec takich informacji geniusze racjonalnego namysłu, tacy jak Arystoteles, św. Tomasz z Akwinu, Immanuel Kant czy

${ }^{1}$ Andrzej L. Zachariasz powie, że ponowożytny (ponowoczesny) „rozum zostaje jeśli nie wręcz odrzucony, to co najmniej w swoich dotychczasowych uprawnieniach zanegowany. Znalazło to wyraz (...) w próbach negowania filozofii jako poznania teoretycznego, nauki jako wiedzy znajdującej uzasadnienie w metodach poznania intersubiektywnego, a w konsekwencji również w negacji idei porządku (kosmosu), w negacji wszelkich unormowań życia społecznego, kodeksów moralnych, etyki itd." (Zachariasz, 1996: 27). 
Pascal wydają się niedouczeni, a może nawet niekompetentni. Czyżby zatem nasza wcześniejsza sugestia o deficycie współczesnego rozumowania była błędna?

Niestety, kryzys rozumowania zdaje się zjawiskiem dość powszechnym, jednak sam, będąc komponentem aksjologicznego chaosu, często jest niezauważalny. Wszak współczesny człowiek - i to często niezależnie od wykształcenia - po prostu już nie wie, czym tak naprawdę jest myślenie jako czynność typowo ludzka. Wydaje mu się, że rozumować to po prostu wpatrywać się w ekran monitora i biernie zanurzyć się w nurcie spostrzeżeń wzrokowych czy dźwiękowych i świadomościowo pochłaniać kolejny kompleks danych ${ }^{2}$.

Protestując przeciwko temu teoriopoznawczemu mitowi, zapytajmy jednak: cóż z tego, że współczesny człowiek zazwyczaj wie, że istnieją pulsary, kwazary, czarne dziury et cetera, jeżeli to Immanuel Kant (nie mający o tym najmniejszego pojęcia) z pasją napisał: „Dwie rzeczy mnie fascynują - niebo gwiaździste nade mną i prawo moralne we mnie” i jeżeli to Pascal stwierdził, że „człowiek jest tylko trzciną, ale trzciną myślącą”? W tych zdaniach wyraża się geniusz ludzkiego rozumu, który podziwia świat i, będąc nim zafascynowany, ciągle zadaje mu pytanie: dlaczego istnieje i co jest w nim najważniejsze (co jest jego istotą). Zdania te są też instruktażowe dla nas, wszak pokazują, że rozumowanie jest zaprzeczeniem czystej receptywności i oznacza aktywny, angażujący całą osobę krytyczny(!) ruch rozumu w stronę prawdy ${ }^{3}$.

Tyle tylko, że współczesny człowiek wątpi w istnienie prawdy. Nie ufa już ani sobie, ani światu. Patrzy, patrzy - tak jak obojętny i zblazowany widz obserwujący rywalizację sportową. I po cichu mówi sobie: bez sensu. Bez sensu jest wyścig biegaczy czy rywalizacja graczy. Ale bez sensu jest zupełnie wszystko: życie, miłość, praca, rodzina; bez sensu zresztą jest istnienie kosmosu. Dzisiejszy człowiek (Bauman powiedziałby: człowiek płynnych czasów), zanurzony w aksjologicznym

${ }^{2}$ To potoczne przekonanie wpisuje się w epistemologiczne nieporozumienie, w myśl którego poznanie „powstaje i kształtuje się w wyniku wzajemnego oddziaływania na siebie dwóch rzeczywistości: obiektywnego świata zewnętrznego (przyrody) i świata społecznego (społeczeństwa i kultury) oraz subiektywnej świadomości jednostek. Poznanie jednak jako proces (...) ma rzekomo przebiegać według zasady przyczynowości. Tak zinterpretowane poznanie uchodzi - jako to, co subiektywne za skutek, a obiektywna rzeczywistość przyrody i społeczeństwa za przyczyną lub byt pierwotny" (Siemianowski, Kmiecikowski, 2006: 8).

3 Mając świadomość klasycznych odrębności dystynkcji rozum, intelekt i umysł - kierując się pragmatyką wykładu inauguracyjnego - poprzestajemy na pewnej ich unifikacji. Por. Herbut, 1997: 296n. Mieczysław Krąpiec powie zarówno, że poznawać „to niejako «stawać się» (w sposób szczególny, bo obiektywny) rzeczą (treścią) poznawaną (...)” (Krąpiec, 1986: 173), jak i, że „ «speculabile» jest przedmiotem czysto teoretycznego poznania człowieka, który przez akt poznawczy stara się poinformować o faktycznym stanie rzeczy (...) [a prawda jest - W.K.] i celem tego poznania, i zarazem jego ostatecznym kryterium wartościowości” (Krąpiec, 1986: 186). 
zamęcie, przypomina nieco Piłata, który, rozmawiając z Chrystusem - znana scena z Ewangelii św. Jana albo przynajmniej znana z wybitnej artystycznie Pasji Mela Gibsona - zapyta retorycznie: „Cóż to jest prawda?”; retorycznie, bowiem nie wierzy w jej istnienie (por. Adamski, 2009: 39nn; Bauman, 2007a: 7nn).

Ale współczesny homo sapiens, nawet ten wykształcony i inteligentny, zdaje się wykraczać poza smutek Piłata wątpiącego w obecność Prawdy. Bowiem współczesny znudzony myśliciel (a raczej quasi-myśliciel) coraz częściej przyjmuje postawę pełną pychy intelektualnej i konstatuje: nie ma żadnej prawdy, nie istnieje prawda. Wprawdzie może jeszcze wrzucać w siebie encyklopedyczną wiedzę, strumień informacyjno-obrazowy, lecz wewnętrznie jest pusty i martwy niczym pamięć aparatu fotograficznego, którego obiektyw kieruje się wprawdzie w stronę pięknych pejzaży, lecz która to pamięć wszak sama tego piękna nie dostrzega. Taki człowiek przestał już wewnętrznie pytać i poszukiwać różnorodnych dlaczego (dlaczego przyjaciel mnie zdradził, dlaczego toczy się wojna, dlaczego uczestniczę bądź nie uczestniczę w wydarzeniu religijnym czy dlaczego jeszcze, znudzony, nie uciekłem z tej auli). Pytanie dlaczego staje bezsensowne, skoro wszystko jest fałszem i iluzją. W tej perspektywie pytajność pytania, owo „«dia ti» (...): «dla-czego», «dzięki czemu»" (Krąpiec, 1999: 31), ulega radykalnej atrofii.

Czy wobec powyższej diagnozy możemy wskazać jakieś panaceum? Wydaje się, że trzeba powrócić do samych źródeł, do tego, co banalnie elementarne, a jednocześnie doniosłe i trudne.

Istotnym momentem zwrotu intelektualnego musi stać się uświadomienie sobie, że prawda po prostu jest. Przecież dzisiejszy sofista - często nieświadomie nawiązujący do starożytnego Protagorasa z jego homo mensura - który mówi: „każdy ma swoją prawdę, nie istnieje obiektywna prawda” popada w sprzeczność; wszak jego konstatacja jest właśnie deklaracją obiektywnej prawdy! Trzeba zatem przypomnieć mu, że skoro twierdzi, że istnieje tylko fałsz i chaos (wraz z głupcami wierzącymi w istnienie prawdy), to przecież... deklaruje pewną prawdę. Już w genialnym Teajtecie Platona pada supozycja, że nie można bez popadnięcia w jawny absurd kwestionować prawdy jako takiej (nawet jeżeli trudno ją znaleźć) (por. Grzeszczak, 2010: 23nn; Kunzmann, 1999: 35; Reale, 1994: 247nn).

Innym terapeutycznym motywem winno stać się przypomnienie wyjątkowej godności człowieka. Wszakże jest on zwierzęciem rozumnym, czyli jedynym bytem w kosmosie zdolnym do rozumnego odkrywania prawdy o zawiłościach świata i sobie samym. To geniusz rozumu człowieka pozwala mu skonstruować skomplikowane narzędzie zwane komputerem, Wielki Zderzacz Hadronów, odkryć grafen, ale także dawać odpowiedzi na pytania o sens życia, naturę przyjaźni czy miłości. Ten geniusz przysługuje wyłącznie człowiekowi i nie dysponuje nim ani 
zwierzę zdeterminowane instynktem, ani najbardziej wyrafinowany robot, którego możliwości działania są wyznaczone planem ludzkiego konstruktora. Albowiem (będąc bytem osobowym) człowiek wprawdzie stanowi fragment przyrody, lecz jednocześnie rozumem, wolą i otwarciem na Dobro i Piękno wyrasta ponad całość wszechświata i zdolny jest nie tylko do aktywności typowo technicznej, lecz także refleksyjnej, moralnej, estetycznej czy religijnej; jest zdolny - jak pisał Ingarden - oddać nawet życie dla ratowania swojego honoru (por. Ingarden, 1987: 15nn; 22nn).

Ale uświadomienie sobie godności fundowanej na tym, że człowiek jest zawsze niepowtarzalną osobą, nie wystarcza jeszcze, aby wyrwać się z chaosu aksjologicznego. Współczesny człowiek musi bowiem zerwać z intelektualnym lenistwem. Terapia winna objąć obudzenie pasji poznawczej - chcieć wiedzieć, chcieć rozumieć, chcieć wnikać w tajemnice bytu, chcieć krytycznie czytać; chcieć - a zatem odrzucić wieczne ZZZ - zapamiętać, zdać, zapomnieć; chcieć odrzucić postawę intelektualnego pochłaniacza informacji zamienionych w kolorowe obrazki. Dzisiejszy człowiek potrzebuje wyrwania się z intelektualnego marazmu i powrotu (a może dopiero nauki) do krytycznego rozumowania. Musi on zerwać z tym, co w duchu Martina Heideggera można określić następująco: „Myśli się tak, jak się myśli; mówi się tak, jak się mówi; czyta się tak, jak się czyta” (por. Stachewicz, 2004: 93). Skoro człowiek jest zawsze niepowtarzalną osobą, to zobowiązany jest do pełnego korzystania $\mathrm{z}$ własnego rozumu, a to oznacza osobistą refleksję i krytycyzm wobec dyktatury opinii powszechnej; krytycyzm, będący uzasadnionym racjonalnie (uargumentowanym!) sprzeciwem, na przykład odnoszonym do tez naszego prezentowanego wykładu.

Na poziomie konkretu oznacza to konieczność czujności naszej świadomości, kiedy słyszymy na przykład, że należy zwierzęta wychowywać (już nie tresować), zwłaszcza że ucznia już nie trzeba wychowywać (vide - antypedagogika) albo że chomik odchodzi czy umiera i że zwierzęta posiadaja prawa analogiczne do praw ludzi (vide - niemoralne staje się bezbolesne usypianie bezpańskich psów, ale już moralne okazuje się bezbolesne usypianie chorych psychicznie). Notabene: już w 1933 roku wprowadzono ustawę o ochronie praw zwierząt, a przywódca pewnego europejskiego państwa zapowiedział, że nie będzie już w nim okrucieństwa wobec zwierząt. Nie wiem, może nie było, ale było nieprawdopodobne okrucieństwo wobec ludzi. Albowiem te obietnicę złożył Adolf Hitler w nazistowskich Niemczech $^{4}$.

${ }^{4}$ Szczególną ilustracją naszych rozważań staje się konstatacja Urszuli Zarosy, że „jednym z najprostszych i satysfakcjonujących rozwiązań problemu występowania świadomości u zwierząt 
Szanowni Państwo. Myśląc, będąc krytycznymi, a zatem wynurzając się powoli $\mathrm{z}$ aksjologicznego zamętu, być może zauważymy, że ulegamy intelektualnej mistyfikacji nakazującej nam powiedzieć sponsoring zamiast wyrafinowana prostytucja albo profesjonalista zamiast morderca (patrz: Leon zawodowiec z Jean Reno); tej mistyfikacji, która niedostrzegalnie zamienia tolerancję w aprobatę (wszak będąc ateistą - bądź teistą - mogę jedynie tolerować osobę wierzącą (ateistę), a nie aprobować jej poglądów, bo to oznaczałoby rezygnację z mojego własnej orientacji światopoglądowej i przyjęcie za własne obcych mi poglądów) ${ }^{5}$.

W świetle powyższych uwag możemy odczuwać radość, jeżeli uderzy nas fakt manipulacji nami, bo to oznacza pewną suwerenność wobec chaosu aksjologicznego, na przykład manipulacji poprzez sieć programów telewizyjnych uprawiających metafizykę długości paznokci, ilości kropek białych i zielonych na rzeczonych paznokciach, ewentualnie dramatycznym wyborze koloru krawata czy wreszcie na filozofii życia celebrytów, którzy przeżywają dramat związany z tym, że paparazzi uchwycili ich bez makijażu bądź z nowym partnerem. W chwili pracy nad tym

jest przyjęcie, że prawdopodobnie doznają one podobnych wrażeń i stanów mentalnych jak ludzie. Świadomie odczuwają ból, potrafią używać narzędzi, uczą się z przeszłych doświadczeń, oczekują przyszłych zdarzeń (...). Istnieje wiele badań opisujących przykłady rozumności, intencjonalności działań, komunikacji czy zachowań wskazujących na występującą w świecie zwierząt świadomość" (Zarosa, 2016: 125n). Wypowiedź ta koresponduje ze stwierdzeniem autorki - pojawiającym się w kontekście przemocy stosowanej przez niektóre organizacje broniące zwierząt - że „Z perspektywy etyki nawet aktywizm, w którym pojawiają się elementy przemocy, może być akceptowalny (...)" (Zarosa, 2016: 251, por. 243nn). Por. https://pl.wikipedia.org/wiki/Prawa_zwierz\%C4\%85t, dostęp: 22.11.2016; http://niechcianeizapomniane.org/swiatowa-deklaracja-praw-zwierzat/, pobrano: 22.11.2016. „Ogólną formułą antypedagogiki - pisze Stefan Wołoszyn - jest zasada wspierać a nie wychowywać" (Wołoszyn, 1998: 132), a Hubertus von Schoenebeck wprost stwierdza, że „obowiązuje zasada: (mały) człowiek nie jest istotą, którą należy wychowywać (nie jest homo educandus) (von Schoenebeck, 1994: 24). Ten sam autor zresztą z dumą pisze: „mam dwoje dzieci w wieku 8 i 10 lat i one nie były wychowywane" (von Schoenebeck, 1992: 249). Por. także: http://www.rp.pl/ Sluzba-zdrowia/307249819-W-Holandii-rosnie-liczba-eutanazji-psychicznie-chorych.html, dostęp: 22.11.2016.

${ }^{5}$ Aprobata wszak jest to „sąd zawierający pozytywną pod względem moralnym, estetycznym lub utylitarnym ocenę czegoś" (Podsiad, 2000: 66n). Por. http://m.deon.pl/inteligentne-zycie/obiektyw/art,416,uniwersytutki.html, dostęp: 22.11.2016; por. M. Bańko, http://sjp.pwn.pl/poradnia/szukaj/tolerancja.html, dostęp: 24.11.2016, Łobocki, 2006: 110nn. Piotr Jaroszyński powie, że tolerancja „należy do kanonu kategorii etycznych promowanych przez ideologię socliberalną (...)” (Jaroszyński, 2016). Warto w tym momencie przytoczyć nieco ogólniejszą refleksję Ryszarda Wiśniewskiego, który twierdzi, że współcześnie „uczy się socjotechniki oraz psychotechniki na kursach marketingu czy kształtowania wizerunku (public relations). Umiejętności manipulacyjne służą osaczaniu partnerów współżycia i komunikacji (...). Na bełkot zarówno aksjologiczny, jak i logiczny narażona jest szczególnie manipulacja marketingowa, perswazja i publiczne, natrętne moralizatorstwo, które upraszczają świat wartości (...)" (Wiśniewski, 2009: 164). 
wykładem dowiedziałem się - ku radości i smutkowi milionów ludzi - że Brad Pitt i Angelina Joli, Państwo nie uwierzą: rozwodzą się... To szyderstwo ma oczywiście sprzyjać wyeksponowaniu powszechności wielokierunkowej i uwłaczającej godności rozumnego człowieka aksjologicznej sofistyce, której często stajemy się ofiarami. Będąc nimi, nie dostrzegamy nawet, że reklamy zamieniają nas $w$ konsumenckie marionetki, czujące się szczęśliwe po zakupieniu konkretnego kosmetyku czy wycieraczki do auta; marionetki, które w wydaniu męskim modelują swój umysł i ciało przez matrycę metroseksualizmu, a w żeńskim wariancie przez matrycę wymiarów tej czy innej części ciała. Współczesne kukiełki w teatrze świadomościowego kuglarstwa, które w samym zamierzeniu depersonalizuje - zamraża geniusz ludzkiego rozumu - przyjmują w siebie (niczym bierna i bezwolna plastelina) przesąd, że w życiu ma być łatwo, miło, sympatycznie, bezproblemowo, kolorowo, spokojnie. Przesąd fatalny, bo nieprawdziwy i niszczący samą naturę człowieka, każdego człowieka - zarówno tego, kto mu ulega, jak i jego otoczenia ${ }^{6}$.

Bowiem zniewoleni mentalnie aktorzy - wierzący, że ma być miło i łatwo często nie widzą już wokół siebie innych osób. Widzą już tylko ich użyteczne dla siebie funkcje. Stąd anihilują mentalnie lekarza do medycznej kompetencji, pacjenta do schorzenia, sprzątaczkę do czyszczącej funkcji, studenta do numeru, a profesora do wpisywacza ocen do WD, USOS czy innego systemu. Rodzic przestaje być rodzicem, a staje się usługodawcą, a dziecko - życzeniobiorcą (czasami bardzo nachalnym, notabene skutecznie kształtowanym przez media sprzyjające często permisywizmowi moralnemu i intelektualnemu ${ }^{7}$ ).

${ }^{6}$ „Reklamy i wyborcze kampanie (...) destruują potrzebę ładu aksjologicznego, sensu, prawdy, dobra moralnego i ładu estetycznego. Współczesny człowiek coraz częściej zadowala się pozorem sensu, pozorem prawdy, pozorem moralności" (Wiśniewski, 2009: 164n). Wspomniane w tekście konsumenckie marionetki zdają się coraz bardziej urzeczywistniać doskonałego konsumenta, o którym pisał Zygmunt Bauman (2007b: 144). Andrzej Gorlewski celnie zauważa, że „poziom wychowania młodzieży (...) napełnia lękiem i obawą. W świecie młodego człowieka dominującą rolę odgrywają szeroko pojęte antywartości. To one promują wątpliwej jakości działania (...), które są podejmowane bez oglądania się na skutki, jakie owe działania niosą dla drugiego człowieka czy społeczeństwa" (Gorlewski, 2009: 321).

7 Piotr Żuk stwierdza, że „nie tylko poważne gazety, walcząc o przetrwanie, upodobniły się $\mathrm{w}$ dużym stopniu do tabloidów, ale również telewizyjne programy informacyjne zamieniły się w programy plotkarskie (...). W ten sposób poważne debaty dotyczące spraw społeczno-ekonomicznych spychane są na bok przez zalew infotainmentu, w którym obok niusów o zbrodniach, morderstwach czy też skandalach z życia polityków pojawiają się sentymentalne historyjki o ślubach, rozwodach i zdradach w kręgach celebrytów medialnych" (Żuk, brak roku : 203n., por. Zwiefka-Chwałek, 2008: 80nn; Suska, 2008: 380nn; Jeran, 2009: 329nn). Znacząco brzmi konstatacja (odwołująca się do A. Hilla), że „reality show oraz programy dotyczące stylu życia «robią widowisko z kryzysów etycznych». Nie ma tutaj wyraźnego podziału na dobre i złe zachowanie, chodzi raczej o nieustanny niepokój o problemy etyczne i kulturowe normy zachowania, przez który programy «zachęcają nas 
Współczesny aktor aksjologicznego zamętu zdaje się utrwalać i wciąga innych w przestrzeń fałszu, bowiem, traktując innych jak wspomniane funkcje, zamienia ich w rzeczy i nie tylko depersonalizuje, lecz każdym swym nieetycznym gestem utrwala w nich owo kłamliwe przekonanie, że w życiu - powtórzmy - ma być łatwo, miło, sympatycznie, bezproblemowo, kolorowo, spokojnie. Ale to jest współczesne globalne kłamstwo. Bo w życiu ma być po prostu uczciwie. Genialny Immanuel Kant mówił o prawie moralnym we mnie i o tym, że drugi człowiek nie może być traktowany jak przedmiot. Inka (której imię dostojnie towarzyszy bliskiemu nam leszczyńskiemu rondu) podkreśli to jako zachować się jak trzeba, a Jacek w Rodzinie zastępczej (grany przez Piotra Fronczewskiego) powie: tylko zdechłe ryby plynq $z$ prądem. Owa $z$ dechła ryba przypomina naszego współczesnego zniewolonego mentalnie aktora, który nie widzi i nie chce dostrzec moralnego dobra spowijającego zmęczonych troską rodziców, wolontariuszy w Syrii czy każdego, kto uczciwie wykonuje swoją pracę; aktora, który płynie z prądem negatywnych wartości Romana Ingardena - niesprawiedliwości, kłamstwa, wiarołomstwa, tchórzostwa, nieprawości, pychy, egoizmu, mściwości czy interesowności ogołoconej zupełnie z szacunku wobec innych ludzi (por. Ingarden, 1989: 14, 252nn; 1970: 233).

Tylko człowiek rozumny - wbrew coraz powszechniejszej akceptacji dla nurtu zła - dostrzeże Dobro, które współ-przenika się z Prawdą. Tylko, będąc krytycznie myślącym studentem, profesorem, kasjerem, dostrzegę, że określenia typu: wszyscy kłamią i oszukują, nie istnieje sprawiedliwość, każdy myśli tylko o sobie, są po prostu nieprawdą, która służyć może tuszowaniu jedynie własnej niegodziwości. Jeżeli sierżant Michel Ollis w 2013 roku oddał w Afganistanie życie za polskiego żołnierza (zasłonił go własnym ciałem przed wybuchem ${ }^{8}$ ), to znaczy, że moralne dobro jest twardym, realnym faktem, którego kwestionowanie jest jedynie wyrazem mentalnej niedojrzałości. Wyrazem tej ostatniej jest także bezkrytyczne akceptowanie kultu brzydoty. Wszak jeżeli dziecko jest oswajane - poprzez z założenia antyestetyczne, krzykliwe postaci z kreskówek czy wręcz wampiryczne lalki Monster High - z brzydotą pozorującą piękno, to jak budować w nim wrażliwość na piękno świata? A może chodzi właśnie o to, aby dzisiaj człowiek uwierzył już

do wejścia w strefę etycznej niewiadomej»” (Briggs, 2012: 56). Exemplum refleksji zawartych w wykładzie może być także konstatacja, że „Zwolennicy hipotezy «spodlonego świata» (...) stwierdzają, że wpływ telewizji na widzów przejawia się przede wszystkim w wytwarzaniu poczucia strachu, zagrożenia, nieufności i znacznej bezradności” (Lemish, 2008: 120).

${ }^{8}$ Por. http://wiadomosci.dziennik.pl/swiat/artykuly/438214,afganistan-atak-na-baze-w-ghazni-amerykanin-ocalil-polskiego-zolnierza.html, dostęp: 22.11.2016; http://usa.se.pl/nowy-jork/ newsy/oddal-zycie-za-polaka-rodzice-nowojorskiego-bohatera-ktory-wlasnym-cialem-zaslonil-naszego-zolnierza_365993.html, dostęp: 22.11.2016. 
nie tylko w bezsens prawdy i dobra, lecz także w szpetotę świata i to wbrew pięknu zaklętemu w dziełach sztuki, w szumie jesiennych, kolorowych liści czy w blasku kochanych oczu. Wszak świat bezsensowny, zły i szpetny, to świat, któremu już nie potrzeba żadnej Pierwszej Przyczyny czy Największej Doskonałości kochającej ów świat ${ }^{9}$.

Reasumując. Leszczyński, jak pamiętamy, wyrażał nadzieję, że człowiek wykształcony jest moralny z wyboru. Ufam, że refleksja, w której uczestniczymy, nieco uprawdopodobni realizację tego oczekiwania i rzeczą oczywistą będzie łączenie imperatywu dydaktycznego z imperatywem moralnym. Ufam wszak, że każdy uczestnik dzisiejszej inauguracji doskonale wie, że powołaniem człowieka jest osiąganie mądrości, czyli - jak sugeruje Antoni Podsiad - po prostu umiejętność rozróżniania prawdy i fałszu, dobra i zła, piękna i brzydoty i kierowanie się w życiu tymi pozytywnymi bytowymi drogowskazami - także w trakcie trwania aktualnego roku akademickiego, czego Państwu i sobie życzę.

\section{Literatura}

Adamski A. (2009). Koncepcja prawdy jako wybór moralny człowieka. [W:] D. Probucka (red.). Prawda w życiu moralnym i duchowym. Kraków.

Amerykański żołnierz oddał życie za Polaka. Zasłonit go własnym ciałem. (2016). http://wiadomosci. dziennik.pl/swiat/artykuly/438214, afganistan-atak-na-baze-w-ghazni-amerykanin-ocalil-polskiego-zolnierza.html, dostęp: 22.11.2016.

Bańko M. (2016). Tolerancja. http://sjp.pwn.pl/poradnia/szukaj/tolerancja.html, dostęp: 24.11.2016. Bauman Z. (2007a). Płynne czasy. Życie w epoce niepewności. Warszawa.

Bauman Z. (2007b). Plynne życie. Kraków.

Briggs M. (2012). Telewizja i jej odbiorcy w życiu codziennym. Kraków.

Galińska I. (2018). Uniwersytutki. http://m.deon.pl/inteligentne-zycie/obiektyw/art,416, uniwersytutki. html, dostęp: 22.11.2016.

Gogacz M. (1993). Mądrość buduje państwo. Człowiek i polityka. Rozważania filozoficzne i religijne. Niepokalanów.

${ }^{9}$ W tym miejscu nastąpiło zwieńczenie wystąpienia w następującym brzmieniu: Reasumując. Leszczyński, jak pamiętamy, wyrażał nadzieję, że człowiek wykształcony jest moralny $z$ wyboru. Ufam, że refleksja, w której uczestniczymy, nieco uprawdopodobni realizację tego oczekiwania i rzeczą oczywistą będzie łączenie imperatywu dydaktycznego z imperatywem moralnym. Ufam wszak, że każdy uczestnik dzisiejszej inauguracji doskonale wie, że powołaniem człowieka jest osiąganie mądrości, czyli - jak sugeruje Antoni Podsiad - po prostu umiejętność rozróżniania prawdy i fałszu, dobra i zła, piękna i brzydoty i kierowanie się w życiu tymi pozytywnymi bytowymi drogowskazami - także w trakcie trwania aktualnego roku akademickiego, czego Państwu i sobie życzę (por. Podsiad, 2000: 493n; Gogacz, 1993: 5). 
Gorlewski A., Wartości a wspótczesne kierunki wychowania młodzieży. [W:] E. Okońska, K. Stachewicz (red.). Co się dzieje z wartościami? Próba diagnozy. Poznań.

Grzeszczak J. (red.). (2010). Filozofia. Materiały do ćwiczeń dla studentów teologii. Poznań.

Herbut J. (1997). Intelekt/Rozum. [W:] J. Herbut (red.). Leksykon filozofii klasycznej. Lublin.

http://www.rp.pl/Sluzba-zdrowia/307249819-W-Holandii-rosnie-liczba-eutanazji-psychicznie-chorych.html, dostęp: 22.11.2016.

Ingarden R. (1970). Czego nie wiemy o wartościach. [W:] R. Ingarden, Studia z estetyki, t. 3. Warszawa. Ingarden R. (1987). Książeczka o człowieku. Kraków.

Ingarden R. (1989). Wykłady z etyki. Warszawa 1989.

Jaroszyński P. (2016). Tolerancja. http://www.ptta.pl/pef/pdf/t/tolerancja.pdf, dostęp: 22.11.2016.

Jeran A. (2009). Związki celebrytów w zwierciadle plotek - Doda i Majdan w polskich serwisach plotkarskich. [W:] W. Muszyński (red.). (Roz)czarowanie? Miłość i związki uczuciowe we wspótczesnym społeczeństwie. Toruń.

Kazimierczuk A. (2015). W Holandii rośnie liczba eutanazji psychicznie chorych. „Rzeczpospolita” 24.07.2015.

Krąpiec M.A. (1986). Ja - człowiek. Zarys antropologii filozoficznej. Lublin.

Krąpiec M.A. (1999). Koncepcje nauki i filozofia. [W:] M.A. Krąpiec [i in.] Wprowadzenie do filozofii. Lublin.

Kubik W. (2013). Amerykański żotnierz oddat życie za Polaka. Zasłonił go własnym ciałem. http:// usa.se.pl/nowy-jork/newsy/oddal-zycie-za-polaka-rodzice-nowojorskiego-bohatera-ktory-wlasnym-cialem-zaslonil-naszego-zolnierza_365993.html, dostęp: 22.11.2016.

Kunzmann P. [i in.]. (1999). Atlas filozofii. Warszawa.

Lemish D. (2008). Dzieci i telewizja. Perspektywa globalna. Kraków.

Łobocki M. (2006). Teoria wychowania w zarysie. Kraków.

Okońska E., Stachewicz K. (2009). O wartościach i ich ambiwalencji - uwagi wprowadzające. [W:] E. Okońska, K. Stachewicz (red.). Co się dzieje z wartościami? Próba diagnozy. Poznań.

Podsiad A. (2000). Słownik terminów i pojęć filozoficznych. Warszawa.

Reale G. (1994). Historia filozofii starożytnej, t. 1. Lublin.

Schoenebeck H. von (1992). Rozstanie z pedagogiką. [W:] B. Śliwerski (red.) Edukacja alternatywna. Dylematy teorii i praktyki. Kraków.

Schoenebeck H. von (1994). Antypedagogika w dialogu. Wprowadzenie w myślenie antypedagogiczne. Kraków.

Siemianowski A., Kmiecikowski W. (2006). Zarys teorii poznania. Ujęcie fenomenologiczne. Gniezno.

Stachewicz K. (2004). Człowiek w odniesieniach. Wokót koncepcji Martina Heideggera. „Filozofia Chrześcijańska”, t. 1. Poznań.

Suska D. (2008). Mody kulturowe, mody językowe w czasopismach młodzieżowych. Uwagi o najnowszej przestrzeni medialnej (dla) młodego odbiorcy. [W:] W. Muszyński (red.). „Cudne manowce?”. Kultura czasu wolnego we współczesnym społeczeństwie. Torun.

Światowa Deklaracja Praw Zwierząt uchwalona przez UNESCO w dniu 15.10.1978 w Paryżu. (2016). http://niechcianeizapomniane.org/swiatowa-deklaracja-praw-zwierzat/, dostęp: 22.11.2016.

Wiśniewski R. (2009). Bełkot aksjologiczny w komunikacji międzyludzkiej. [W:] E. Okońska, K. Stachewicz (red.). Co się dzieje z wartościami, Próba diagnozy. Poznań.

Wołoszyn S. (1998). Nauki o wychowaniu w Polsce w XX wieku. Próba syntetycznego zarysu na tle powszechnym. Kielce. 
Zachariasz A.L. (1996). Moralność i rozum w ponowożytności. [W:] Z. Sareło (red.). Moralność i etyka w ponowoczesności. Warszawa.

Zarosa U. (2016). Status moralny zwierzat. Warszawa. https://pl.wikipedia.org/wiki/Prawa zwierz\%C4\%85t, dostęp: 22.11.2016.

Zwiefka-Chwałek A. (2008). Casus Dody, czyli nie ma info bez rozrywki. Analiza „infotainment” we współczesnych polskich programach publicystycznych. [W:] W. Muszyński, M. Sokołowski (red.). Homo creator czy homo ludens? Twórcy - internauci - podróżnicy. Toruń.

Żuk P. (2011). Homo ludens w czasach kapitalizmu. Infantylizacja życia społecznego i prywatyzacja sfery publicznej. „Dialogi o Kulturze i Edukacji” nr 1, s. 203n. 